\title{
The Effectiveness of the Use of Learning Strategies in Delivering the Materials of Disaster Guide Book in Senior High Schools and Vocational High Schools
}

\author{
Muhammad Musiyam ${ }^{1}$, Suharjo ${ }^{2}$, Harun Joko Prayitno ${ }^{3}$, Siti Hadiyati Nur Hafida ${ }^{4}$, \\ Wahyu Widiyatmoko ${ }^{5}$ \\ \{mm102@ums.ac.id ${ }^{1}$, suh254@ums.ac.id², hj220@ums.ac.id ${ }^{3}, \underline{\text { shnh421@ums.ac.id }}{ }^{4}$, \\ ww875@ums.ac.id $\left.{ }^{5}\right\}$
}

\author{
Geography Education Department Universitas Muhammadiyah Surakarta Jl. Ahmad Yani Tromol Pos \\ 1 Surakarta, Central Java, Indonesia ${ }^{1,2,4,5}$ \\ Faculty of Teacher Training and Education Universitas Muhammadiyah Surakarta Jl. Ahmad Yani \\ Tromol Pos 1 Surakarta, Central Java, Indonesia ${ }^{3}$
}

\begin{abstract}
Disaster is a natural thing in Indonesia. High vulnerability to it must be balanced with extensive knowledge of disaster, particularly, that of students. They are subjects who are vulnerable to disasters. Disaster education has been being implemented in the learning system by the use of disaster learning guide book in Klaten Regency. This research was conducted to determine the effectiveness of disaster learning guide book in encouraging the students' disaster preparedness. Quasi experimental design was employed in this research. The form of the design used was Nonequivalent Control Group Design. The respondents of this study were students of three senior high schools and those of two vocational high schools. The data analysis techniques used were pre-test and post-test. The results indicate that the use of learning strategies to deliver the materials of disaster guide book in Klaten Regency had various levels of effectiveness. The use of several active learning strategies always shows better results than the conventional learning/lecture. Active learning strategies can be used to deliver disaster materials in both senior high schools and vocational high schools on the grounds that the students had a deeper understanding of disasters.
\end{abstract}

Keywords: effectiveness, disaster preparedness, disaster guide book, learning strategies

\section{Introduction}

Disasters can occur anywhere and anytime. A disaster is an unavoidable event and will definitely cause victims. Indonesia experiences various types of disasters, both ecological and geological disasters. From 2018 to 2019, there were around 5.244 disasters and 5.086 victims because of them disasters (Indonesia Disaster Information Data, 2019). The data indicate that Indonesian people possess low preparedness in facing the disasters. Rinaldi (2009) [1] states that the level of preparedness of Indonesian society belongs to the very low category, which is represented by the number of victims when a disaster occurs. Even though the government has carried out socializations about disasters, it has not effective yet in increasing the level of the society's preparedness. 
Disaster preparedness is closely related to the capacity of the society in facing disasters [2]. If the society has a high level of disaster preparedness, the impact of disasters can be minimized, and when community preparedness is low, conversely, the impact of the disaster will be greater. School is one of the public facilities that is vulnerable to disasters. Facts prove that students is among the vulnerable groups during disaster situations. They are the next generations of the nation, so they should be able to be resilient in facing the disaster considering the condition of Indonesia territory which is very vulnerable to various types of disasters. Every disaster, especially those belongs to natural disasters, will be very difficult to be predicted. Therefore, the next generation must have a prepared and resilient attitude in facing the disasters.

Disaster preparedness can encourage the realization of society resilience in facing disasters. To encourage the increase of disaster preparedness, disaster education begins to be taught to senior high school and vocational high school students. Disaster education is one of the direct efforts in reducing disaster risks [3]. Schools play a very important role in reducing disaster risks because schools are the source of knowledge. Schools have a crucial role in promoting student safety as a strategy to reduce disaster risks [4]. Students are able to gain knowledge and understanding of various sciences through the learning activities, and teachers have the competence to encourage them to develop responses towards the disasters.

Disaster education becomes a strategy of many countries for disaster risk reduction. Based on the global report in 2013, disaster education has been integrated in the national education curriculum in many countries [5]. In Indonesia, many schools located in high disaster prone areas have integrated disaster education in their school activities. It is also effective in reducing the loss of property and educating the society about the dangers and risks off the disasters so it increases the society's resilience and prevents the disaster tragedies in case they reoccur[6].

Disaster education is a complex education because it is rule and law-crossing; it has two dimensions and is positioned within the framework of safe school policy [7]. The complexity of the disaster education system definitely requires human resources who are able to properly and correctly carry out the disaster education program. The disaster education requires a combination of social and science education. The social education trains the students to develop a caring attitude towards other people and the science education is related to the basic knowledge about disasters. The importance of disaster education encourages the Japanese government to integrate it to the education through the introduction of the environmental conditions of where the students live and by undergoing disaster simulations [8]. Disaster education must be started since the early period. This is based on the fact that in every year, a number of 66 million children worldwide are estimated to be affected by disasters [9].

Disaster education will build the students' understanding of the causes, characteristics, and danger impacts, and develop various competencies and skills to enable them to proactively contribute to the process as an effort of disaster prevention and mitigation. The existence of the disaster education is able to change the students' attitudes and behaviors towards various things in life. It is able to encourage people to get to better understand the safety culture during a disaster situation [10]. Someone who learns about disasters has a more extensive knowledge and therefore, will reduce the level of the panic and has the right perception of disasters [11] [12]. Recently, the understanding of the impacts of disasters on children, vulnerable groups, and student companions is an important stage in building resources and disaster programs [13]. Therefore, disaster education must be carried out even though there are various challenges on its management. 
Among the countries that have integrated disaster education in schools is Japan. The Japanese government focuses the disaster education on the understanding of the disasters through a scientific approach [14]. The approach encourages students to be more active in the learning activities by building a new knowledge or integrating it with their previous knowledge. Disaster education requires an active, interactive, and action-oriented learning that prioritizes learning experiences and saves emotional learning of students. The existence of the disaster education aims to encourage the students to be active in facing disaster risks, by exploring locality and society, also the social, economical, and political structure and dynamics. There are numerous approaches to integrate the disaster education in schools, one of them is through the use of disaster guide book.

The efforts made in improving the knowledge of disasters must be supported by the existence of guidelines or teaching materials on disaster. The use of teaching materials can make it easier for the teacher to deliver the materials to the students through learning strategies and media. Teaching materials that are supported by the use of learning strategies and media will facilitate the teachers to be more effective and efficient in the learning process. In addition, the students can also actively participate in the learning of the disaster materials through the learning strategies and media employed by the teacher. A disaster guide book has been released by the Regional Disaster Management Agency (BPBD) Klaten in accordance with the regulation of the Regent of Klaten Number 6 of 2014. The disaster guide book was applied to schools in Klaten because Klaten is a regency that is prone to volcanic eruptions and earthquakes. Disaster guide books which contain diverse information about disasters are greatly beneficial to the students in order to understand disaster. Ironically, students are often lazy to read them. Students have various types of learning style, and each learning style has its benefits and shortcomings. Teachers as the providers of disaster information must be able to deliver the whole disaster materials contained in the disaster guide book. Teachers need a strategy in delivering disaster material, therefore, this study focused on the use of strategies in delivering disaster material for senior high school and vocational high school students.

\section{Material and Method}

This study used experimental research method with quantitative approach. An experimental research study is conducted to determine the effect of certain treatment towards others in a controlled condition [15]. The experiment design used was Quasi Experimental Design. The form of the quasi experimental design used was Nonequivalent Control Group Design. The data analysis techniques were carried out using pre-test and post-test. The pre-test aimed to determine the students' ability or knowledge before learning the materials of Disaster Learning Guide through the learning strategies and media at the high school level in Klaten Regency. By contrast, the post-test aimed to determine the students' ability or knowledge after learning the materials. The results of the pre-test and post-test were examined using statistical test to obtain the effectiveness of the learning strategies for the delivery of the materials from the Disaster Learning Guide teaching materials. 


\section{Result and Discussion}

The Klaten Regency Disaster Guide Book released by the Regional Disaster Management Agency is the first disaster guide book and is used as a disaster guide in Klaten Regency. The guide book is a handbook for the schools in Klaten Regency in order to improve their preparedness towards disasters. The Klaten Regency Disaster Guidebook has been used by several schools in Klaten Regency, but the identification of the learning strategies that can be used to teach the materials of the book has never been done. The combination of the use of the Klaten Regency Disaster Guidebook and the application of the appropriate strategies are expected to increase the preparedness of students in the school. The use of the disaster guide books and the application of the strategies of delivering the knowledge to each sample school is explained as follows:

\section{A. SMAN 1 Karanganom}

The research to examine the effectiveness of the Klaten Regency disaster guide book at SMA Negeri 1 Karanganom involved one control class and one experimental class. The classes that participated were X MIPA 1 class as the control class and X MIPA 2 class as the experimental class. The number of the students in the control class was 27 students, while that of the experimental class was 31 students. The study was conducted for two lesson hours (90 minutes). It began with a pre-test in both the control class and the experimental class to determine the level of the students' initial knowledge about disasters. In the next stage, the materials derived from the Klaten Regency disaster guide book were learned. The methods in delivering the materials were categorized into two, namely lecture method in the control class and True and False method in the experimental class. In the final stage, the researchers carried out the post-test to measure the students' knowledge level after learning the materials through different strategies.

In the experimental class, the learning process used True or False strategy, where each student was given a paper containing some statements related to the materials. Before the paper was distributed, the students were given 20 minutes to read, understand, and discuss the learning materials. Then, the researchers distributed the aforementioned papers to each student. The students were given 3 minutes to analyze the statements on their paper and had to determine whether they are true or false. After that, they expressed their opinions about the statements on the paper they hold (whether they were true or false) followed by the explanations to their answers. They did it in turn according to the song count. Then, the researchers gave feedback to the explanation from each student. This session lasted for 35 minutes.

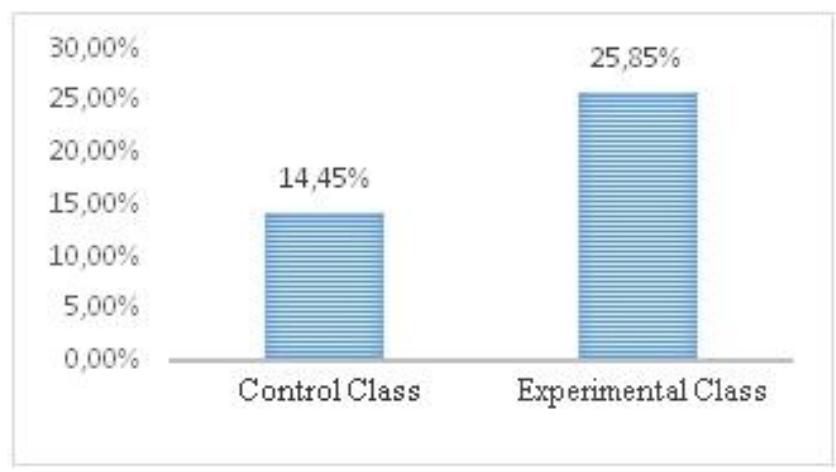


Fig. 1. The comparison of the increase of the value of the pre-test and the post-test using conventional/lecture strategy (control class) and True and False strategy (experimental class) at SMAN 1 Karanganom

The use of the True or False strategy in the learning process had a positive impact. The improvement of the learning outcomes in the experimental class was proven to be higher than that of the control class which used conventional method or lecture in its learning process. The use of the True or False strategy encouraged each student to dare to express their opinions and to discuss so they experienced a more active and effective learning. The comparison of the increase of the learning outcomes using True or False strategy and that using the conventional method can be seen in Figure 1.

In the experimental class, the learning process used True or False strategy, where each student was given a paper containing some statements related to the materials. Before the paper was distributed, the students were given 20 minutes to read, understand, and discuss the learning materials. Then, the researchers distributed the aforementioned papers to each student. The students were given 3 minutes to analyze the statements on their paper and had to determine whether they are true or false. After that, they expressed their opinions about the statements on the paper they hold (whether they were true or false) followed by the explanations to their answers. They did it in turn according to the song count. Then, the researchers gave feedback to the explanation from each student. This session lasted for 35 minutes.

The use of the True or False strategy in the learning process had a positive impact. The improvement of the learning outcomes in the experimental class was proven to be higher than that of the control class which used conventional method or lecture in its learning process. The use of the True or False strategy encouraged each student to dare to express their opinions and to discuss so they experienced a more active and effective learning. The comparison of the increase of the learning outcomes using True or False strategy and that using the conventional method can be seen in Figure 1.

The benefits of True or False strategy that could be observed by the researchers included the fact that the students became more active, that can be proven by the existence of good interactions between the students and their peers and between the students and the teacher. Moreover, the students also dared to give their opinions and respond to the arguments expressed by their classmates. Furthermore, the students were able to solve the problems both individually and in groups. In the learning process, the students had a discussion to find the most appropriate answers, so it stimulated them to be able to complete the tasks given to them. In addition, the interaction between the students and the teacher was well established. Also, the learning became more fun. The shortcoming of the True or False strategy is that it tends to require a long time.

\section{B. SMAN 2 Klaten}

The research study to determine the effectiveness of the use of the learning strategies for the delivery of the materials contained in Klaten Regency disaster guide book at SMA Negeri 2 Klaten used control and experimental classes. X MIPA 4 class was chosen as the experimental class and X MIPA 5 class was the control class. 25 students were participated as the samples of the control class and the other 25 students belongs to the experimental class. The study was conducted by utilizing two lesson hours (90 minutes) in each class. At the early stages of the study, the students were given a pre-test to determine the students' initial knowledge. In the next stage, the students learned the materials derived from the Klaten 
Regency disaster guide book. The students in the experimental class were treated by using role playing strategy, while in the control class the researchers used conventional/lecture strategy. The last step of this study was carrying out a post-test to find out the changes of the students' level of knowledge after they learned the materials about disaster.

The delivery of the materials in the experimental class was initially carried out inside the classroom which began with the explanation of volcanic eruptions, types of eruptions, signs, and early warnings that must be done before until after the eruption. The materials were delivered for 15 minutes. After the materials were explained, the researchers gave a scenario to the students to learn before practicing it outside the classroom. The researchers appointed a director whose job was to organize and direct the characters, i.e. all students who became the research samples. Together with the director, the students did the exercises based on their respective roles until the final preparation inside the classroom, before staging outside the classroom. The training and the final preparation were carried out for 20 minutes with the aim that all students understood their respective roles and the things that must be done by the role. The Role Playing was carried out for 30 minutes. The director directed the characters to play their roles in sequence, based on the scenario prepared by the researchers.

The average value of the Post-Test of the experimental class was 86.56 with a value increase of 30.24, while that of the control class was 67.84 with a value increase of 13.92 . The grounds to this was that during the learning process using Role Playing strategy, the students were more active, dared to present in front of their peers, and directly involved in the process of playing their respective roles.The comparison of the increase in the learning outcomes of the conventional and role playing strategies is presented in Figure 2.

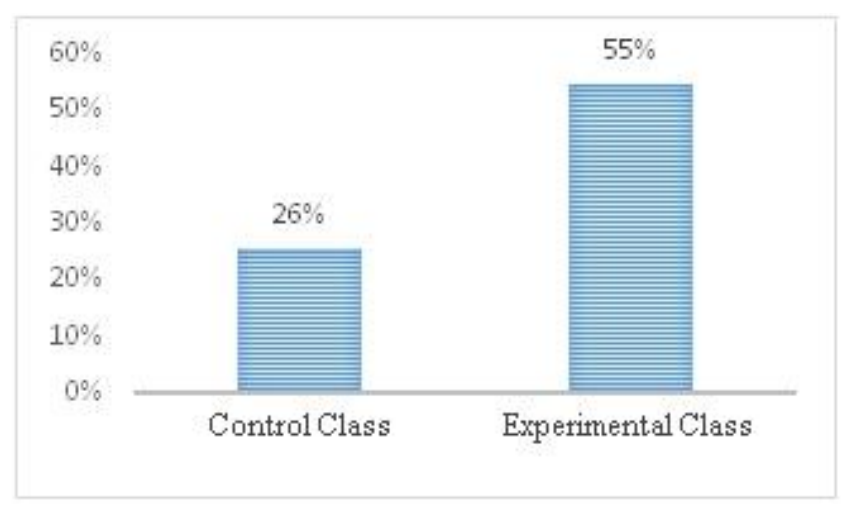

Fig. 2. The comparison of the increase of the value of the pre-test and the post-test using conventional/ lecture strategy (control class) and the Role Playing strategy (experimental class) at SMAN 2 Klaten

Among the benefits of the role playing strategy that can be observed by the researchers was the fact that the students were more active in the learning process. Furthermore, the students did not only listen to the materials delivered by the teacher, but also practiced them. In addition, the students were able to cooperate with all students in playing their roles guided by the director who had been appointed by the researchers. Moreover, the students were free to express when delivering the dialogue when they present the role. Also, it increased the confidence to present and do the dialogue in front of other students. Additionally, the learning was not monotonous and saturated the students, because they learned not only indoors, but also outdoors. Some shortcomings of the role playing strategy were that (1) the learning atmosphere became crowded and noisy when the students practiced acting out their roles and 
dialogue; (2) when the learning took place outside the classroom, the students tend to run around and be unruly to position themselves; and (3) implementing a Role Playing strategy requires a relatively longer time.

\section{SMAN 1 Klaten}

Testing the effectiveness of the strategies used in delivering the materiasl of the Klaten Regency disaster guide book at SMA Negeri 1 Klaten used one experimental class and one control class. The class used as the experimental class was X IPS 2 class, while X IPS 1 class was the control class. The number of the students of the experimental class was 25, and that of the control class was also 25. The experimental class used role playing strategy when the researchers delivered the materials, while the control class used conventional/lecture strategy. Before delivering the materials from the Klaten Regency disaster guide book for each class, the researchers gave a pre-test to the students to find out the students' initial knowledge before being given the treatment. The pre-test took 10 minutes and was then followed by the core activity of providing the materials to the students in the control class and experimental class using different strategies. The post-test was conducted to determine the differences in the level of the students' knowledge about disasters, before and after they were treated.

The increase of the average value of the post-test compared to that of the pre-test in the experimental class was higher than that of in the control class. Providing the materials about earthquake disaster through Role Playing strategy to the students of experimental class fostered the students' understanding of the provided materials and helped them comprehend to the performed roles. Figure 3 shows the comparison of the increase of the learning outcomes between the control class and the experimental class at SMAN 1 Klaten.

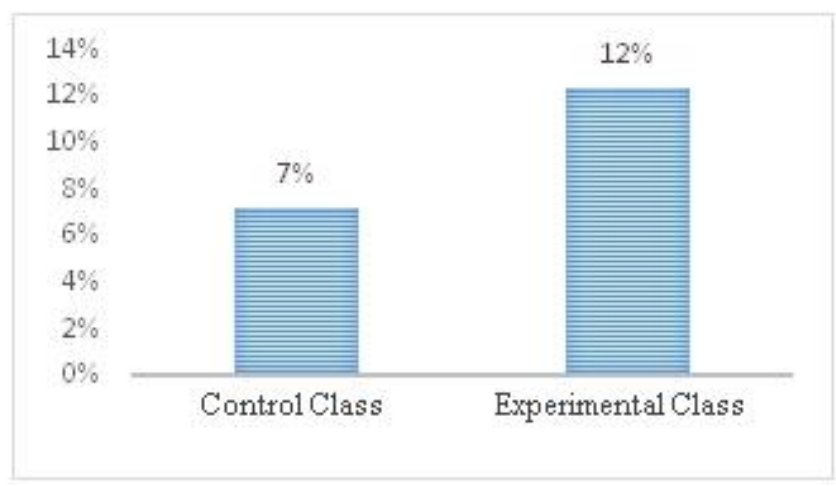

Fig. 3. The comparison of the increase of the value of the pre-test and the post-test using conventional/ lecture strategy (control class) and Role Playing strategy (experimental class) at SMAN 1 Klaten

The benefits of role playing strategy based on the direct observations done by the researchers at SMAN 1 Klaten were that: (1) the learning process was more fun, that was shown by the attitude of each student who acted out their role happily; (2) the students were more active in the learning process (in the Role Playing process, the students actively moved and asked questions then did their roles); (3) the students interacted with each others and fostered a sense of solidarity (the students helped each other to put the paper indicating the 
character's name in Role Playing); the students' skills and attitudes in solving problems were more developed, which was shown by the class leader as a director who was skillful in arranging the Role Playing preparation); (5) the learning materials were more memorable and durable in the students' memories (after the students carried out the Role Playing and then they were evaluated, the learning materials contained in the role playing was more memorable to them); and (6) the students' imagination was trained e.g. when the students played the roles spontaneously, they made a good move in accordance with the pronunciation of the script.

The shortcoming of the application of the role playing strategy was that the students who were appointed to play some roles felt embarrassed when performing certain scenes i.e. the student who acted as the teacher was embarrassed when playing in front of the peers who acted as the students. Moreover, the learning atmosphere was crowded; during the Role Playing, the students were influenced too much by the atmosphere and they were so happy that they laughed too hard and became noisy. In addition, when they were outside the class, some students were busy chatting with their friends. At the time they did not play the role, they were chatting and joking with their friends. Also, it required relatively long time. Role Playing requires preparation; the students had to do the rehearsal and then carry out their roles so that the implementation took relatively long time.

\section{SMK Muhammadiyah 2 Klaten Utara}

The research at SMK Muhammadiyah 2 in Klaten Utara involved extracurricular Disaster Mitigation Team. This extracurricular activity has existed since 2015. Students who took the extracurricular activities were divided into two groups, with each group consisted of 20 students. The division of the groups aimed to determine the use of the Klaten Regency disaster guide book with two different treatments. Group A of the extracurricular Disaster Mitigation Team was the experimental class who learned using Numbered Heads Together (NHT) learning strategy, while group B was used as the control class and learned by lecture conventional strategy. The students were given the pre-test to determine the students' initial knowledge before being treated. The delivery of the disaster materials employed different strategies, but the same materials given to the control class and experimental class. At the end of the study, the students underwent a post-test to determine the changes in the level of the students' knowledge after being given the materials using different strategies.

The NHT (Numbered Heads Together) learning strategy was done by delivering the materials first by the researchers, then the students were formed into 5 groups, each group was given 1-5 head numbers that must be worn. The researchers gave a number of questions about the delivered and explained materials of disaster to the head number who was mentioned by the researchers, and groups 1-5 must be prepared to answer it. The student who was given the opportunity to answer the question was fastest to raise their hands. 


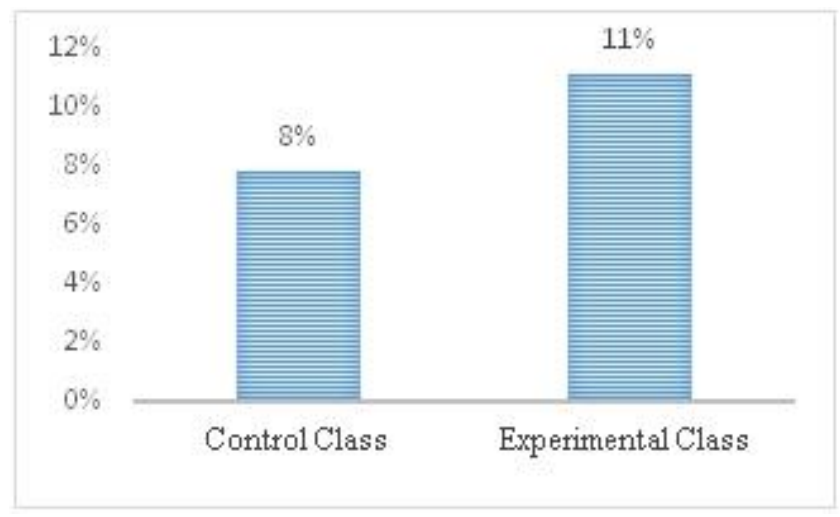

Fig 4. The comparison of the increase of the value of the pre-test and the post-test using conventional/ lecture strategy (control class) and the NHT strategy (experimental class) at SMK Muhammadiyah 2 Klaten Utara

The research study conducted in the experimental class using Numbered Heads Together (NHT) strategy could increase the students' knowledge of disaster materials. The increase of the knowledge in the experimental class was proven by the increase of the average of the posttest value which was higher than that of the control class. The graph of the increase of the post-test value between the control class and the experimental class can be seen in Figure 4 . The result shows that the increase of the knowledge level of the experimental class was higher because of the use of Numbered Heads Together strategy which required the students to interact, explain, and work together in small groups henceforth the researchers gave several questions to each group, so the students became more active in the class.

\section{E. SMK Kristen 5 Klaten}

The research study conducted at SMK Kristen 5 Klaten aimed to determine the comparison of index card match learning strategy and conventional/lecture strategy in learning the materials existed in Klaten Regency disaster guide book. The students who were targeted in this study were the students who took extracurricular activities of the Disaster Alert School. They were divided into two groups: Group A as the experimental class and group B as the control class. The experimental class in this study applied the index card match learning strategy, while the control class used conventional/lecture strategy. In the initial stage, the students were given a pre-test question to determine the students' initial knowledge, then they experienced treatment by getting the similar materials with different learning strategies between the experimental class and the control class. In the final stage, the students were given a post-test to measure the students' knowledge after being treated so that the increase of the knowledge level between the experimental class and the control class could be measured.

The implementation of the index card match strategy was done by distributing separate index cards containing questions and answers in which the students were asked to read and understand the contents. After the students understand the contents of the index card, the students were asked to look for the pair of the obtained index card. The students who had already gotten their partner cards were then asked to sit together and were forbidden to tell the contents of the card to the other friends who were not their partners. After all couples sat down, the students were asked to quiz their friends. The students who had not yet gotten their index card pairs were asked to come forward and line up. The students lining up in front then sequentially look for their index cards pairs. For those who had found the index card pairs and 
the time to look for it was up, they kept sitting in a row in front. The students who had been sitting with their index partners then presented or challenged the other partners. The students who wanted to challenge the other partners were asked to raise their hands.

The test results of the average difference between the control class and experimental class are presented in Figure 5. The class that applied the Index Card Match strategy obtained an average of $71.25 \%$, while that with conventional learning obtained an average of $62.20 \%$. It means that the student's learning outcomes of which learning process employed the Index Card Match learning strategy was better and improved compared to the one employing the conventional learning.

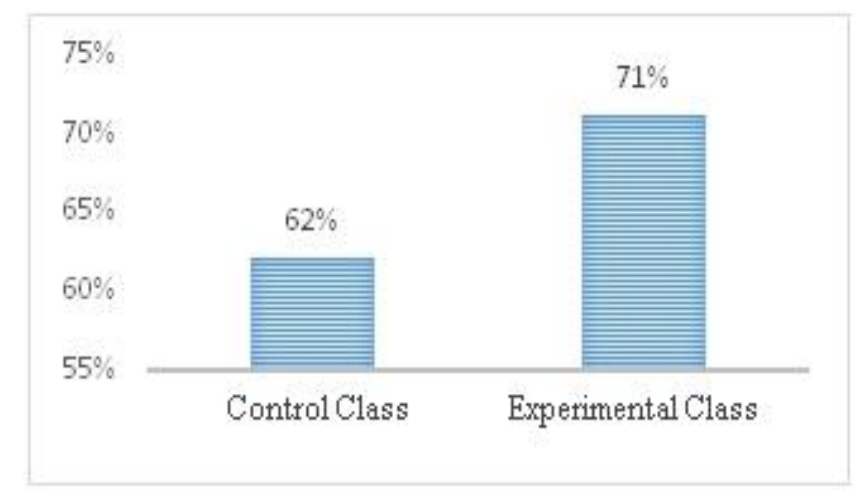

Fig. 5. The comparison of the increase of the value of the pre-test and the post-test using conventional/ lecture strategy (control class) and the index card match strategy (experimental class) at SMK Kristen 5 Klaten

\section{Conclusions}

The use of learning strategies to deliver the materials contained in Klaten Regency Disaster Guide Book had different levels of effectiveness. The use of several active learning strategies always shows the better results than the conventional learning/lecture. It can be concluded that the use of active learning strategy can be used to deliver the disaster materials in senior high schools and vocational high schools because the students had a better improvement in understanding the disasters.

\section{Acknowledgement}

The researchers would like to thank the Ministry of Research and Higher Education for funding this research so that this research could be carried out properly. The researchers would also express their gratitude to the students who participated in this research and the partner schools who were willing to work with the researchers. 


\section{References}

[1] Rinaldi. 2009. Kesiapan Menghadapi Bencana Pada Masyarakat Indonesia. Universitas Negeri Padang. Jurnal Penelitian Psikologi, 14(1).

[2] Lelisa Sena and Kifle W/Michael. 2006. Disaster Prevention and Preparedness. Ethiopia: Jimma University and Ethiopia Public Health Training Initiative

[3] Amri, A. 2015. Challenge in Implementing Disaster Risk Reduction Education: Views from The Frontline in Indonesia. Macquarie University: Sydney, Australia.

[4] Baytiyeh, H. (2017). Can Disaster Risk Education Reduce the Impacts of Recurring Disasters on Developing Societies?. Education and Urban Society, 26(1)

[5] Ronan, K. R. (2014). Advances and Continuing Challenges towards HFA2 and Post-2015: Background Chapter. UNESCO and UNICEF, Paris, France, Geneva, Switzerland.

[6] Petal, M. 2008. Disaster Prevention for Schools Guidance for Education Sector Decision-Makers. Geneva, Switzerland: United Nations International Strategy for Disaster Reduction.

[7] Kitagawa, K. (2015). Continuity and Change in Disaster Education in Japan. History of Education, 44(3), p.371-390

[8] Fujioka, T., Sakakibara,Y. (2018). School Education for Disaster Risk Reduction in Japan After The 2011 Great East Japan Erthquake and Tsunami (GEGET). Terrae Didatica, 14 (3), p. 313-319

[9] F Herdwiyanti, Sudaryono. 2013. Perbedaan Kesiapsiagaan Menghadapi Bencana Ditinjau dari Tingkat Self-Eff icacy pada Anak Usia Sekolah Dasar di Daerah Dampak Bencana Gunung Kelud. Jurnal Psikologi Kepribadian dan Sosial Volume 2, No. 01

[10] Baytiyeh, H., \& Naja, M. K. 2014. "Can education reduce Middle Eastern fatalistic attitude regarding earthquake disasters?”. Disaster Prevention and Management: An International Journal, 23 , p. 343-355

[11] Ronan, K. R., Johnston, D. M., Daly, M., and Fairley, R. (2001). School Children's Risk Perceptions and Preparedness: A Hazards Education Survey". Australasian Journal of Disaster and Trauma Studies, 1.

[12] Ronan, K. R., \& Johnston, D. M. (2003). Hazards Education for Youth: A Quasi-Experimental Investigation. Risk Anal, 23, p. 1009-1020.

[13] Emily Berger, Matthew Carroll, et al. (2018). Disaster Impacts on Students and Staff from a Spesialist, Trauma-Informed Australian School. Journal of Child \& Adolescent Trauma.

[14] Shiroshita, H., Kawata Y. (2007). Institutional Problems in Disaster Education in Compulsory Schooling Analyzed from The Historical Transition of The Course of Study (Japanese National Curriculum). Journal of Japan Society for Natural Disaster Science, 26(2) , 169-70

[15] Sugiyono. 2010. Metode Penelitian Pendidikan Pendekatan Kualitatif, Kuantitatif, dan R\&D. Bandung: Alfabeta 